\author{
HANNA JOKELA \\ etunimi.sukunimi@utu.fi \\ Kirjoittaja on yliopistonlehtori suomen \\ kielen ja kulttuurin (ei-äidinkielisille) \\ oppiaineessa Turun yliopistossa.
}

\section{Lähteet}

Givón, T. 1983: Topic continuity in discourse. A quantitive cross-language study. Amsterdam: John Benjamins.

_ 2011: Ute reference grammar. Amsterdam: John Benjamins.

Hakulinen, Auli - Laitinen, Lea 2008: Anaforinen nolla. Kielioppia ja affekteja. - Virittäjä 112 s. 162-185.

Heinonen, Tarja Rittta 1995: Null subjects in Finnish. From either-or to more-or less. - Tapio Hokkanen, Marja Leinonen \& Susanna Shore (toim.), SKY journal of linguistics 1995 s. 47-78. Helsinki: Suomen kielitieteellinen yhdistys.

Helasvuo, Marja-Liisa - Laitinen, LEA 2006: Person in Finnish. Paradigmatic and syntactic perspectives. - Marja-Liisa Helasvuo \& Lyle Campbell (toim.), Grammar from the human perspective. Case, space, and person in Finnish s. 173-208. Amsterdam: John Benjamins.
ISK = Hakulinen, Auli - Vilkuna, Maria - Korhonen, Rittta Koivisto, Vesa - Heinonen, Tarja RittTa - Alho, IrJa 2004: Iso suomen kielioppi. Suomalaisen Kirjallisuuden Seuran Toimituksia 950. Helsinki: Suomalaisen Kirjallisuuden Seura.

Jokela, Hanna 2012: Nollapersoonalause suomessa ja virossa. Tutkimus kirjoitetun kielen aineistosta. Turun yliopiston julkaisuja, Annales Universitatis Turkuensis C 334. Turku: Turun yliopisto. http://urn.fi/ URN:ISBN:978-951-29-4912-o.

LAitinen, LEA 1995: Nollapersoona. - Virittäjä 99 s. 337-358.

_ 2006: Zero person in Finnish. A grammatical resource for construing human reference. - Marja-Liisa Helasvuo \& Lyle Campbell (toim.), Grammar from the human perspective. Case, space, and person in Finnish s. 209-233. Amsterdam: John Benjamins.

VÄÄNÄNEN, Milja 2016: Subjektin ilmaiseminen yksikön ensimmäisessä persoonassa. Tutkimus suomen murteista. Turun yliopiston julkaisuja, Annales Universitatis Turkuensis C 430 . Turku: Turun yliopisto. http://urn.fi/ URN:ISBN:978-951-29-6664-6.

\title{
Empiiristä kognitiivista kielitiedettä
}

Milla Luodonpää-Manni, Esa Penttilä \& Johanna Viimaranta (toim.): Empirical approaches to cognitive linguistics. Analyzing real-life data. Newcastle upon Tyne: Cambridge Scholars Publishing 2017. 350 s. ISBN 978-1-4438-7325-3. 1970-luvulla formaaliseen kielenkuvauksen perinteeseen reaktiona syntyneellä kognitiivisella kielentutkimuksella on Suomessa pitkä traditio. Sen teorioita ja menetelmiä on hyödynnetty erityisesti fennistiikassa monipuolisesti 1980-1990-lukujen vaih- 
teesta lähtien (esim. Leino 1988, 1989, 1993) muun muassa monessa väitöskirjassa (ks. esim. Huumo 1997; Onikki-Rantajääskö 2001; Nurminen 2015; Möttönen 2016). Milla Luodonpää-Mannin, Esa Penttilän ja Johanna Viimarannan toimittama artikkelikokoelma Empirical approaches to cognitive linguistics: Analyzing real-life data tuo oman panoksensa suomalaiseen kognitiivisen kielentutkimuksen kenttään esittelemällä perinteisen laadullisen empiirisen metodologian lisäksi määrällisiä ja kokeellisia menetelmiä ja niitä hyödyntäviä tutkimuksia. Englanniksi kirjoitettu teos ei ole tarkoitettu pelkästään suomalaisille tutkijoille, vaan se pyrkii myös esittelemään suomalaista tutkimusta kansainväliselle yleisölle. Suomen kielen lisäksi teoksessa käsitellään muita kieliä englannista venäjään. Indoeurooppalaisen alueen ulkopuolelta tulevia kieliä (suomea lukuun ottamatta) ei kuitenkaan ole mukana.

Kokoelma on syntynyt FiCLAn eli Suomen kognitiivisen kielitieteen yhdistyksen vuosina 2014 ja 2015 järjestämien työpajojen pohjalta. Kielitieteen päivillä pidettyjen työpajojen tarkoitus oli pohtia sitä, millaisin menetelmin erityyppisiä korpusaineistoja voidaan hyödyntää kieliopillisten ja semanttisten ilmiöiden tutkimisessa. Tämä kysymys on myös teoksen artikkeleita yhdistävänä punaisena lankana (s. 4). Aiheiden kirjo on laaja: teoksessa käsitellään muun muassa verbien ja prepositioiden semantiikkaa, kielitieteen terminologisia valintoja sekä kielenomaksumista. Myös tutkimusaloja on monia, kuten psykolingvistiikka, käännöstiede ja kontrastiivinen kielitiede.

Teos koostuu yhdeksästä tutkimusartikkelista sekä niitä taustoittavasta johdannosta. Tutkimusartikkelit hyödyntävät yhtäältä korpusmenetelmiä, joita esitellään kokoelman ensimmäisessä osiossa, toisaalta kyselyihin tai koeasetelmiin perustuvia menetelmiä, joihin pureudutaan jälkimmäisessä osiossa. Jako on toimiva siitäkin huolimatta, että toiseen osioon on sisällytetty myös monimenetelmälliset eli korpuksia ja kyselyitä yhdistävät tutkimukset.

\section{Intuitiota ja käyttöpohjaisuutta}

Johdantoluku tarjoaa kattavan metateoreettisen katsauksen teoksen aihepiiriin. Siinä toimittajat esittelevät kognitiivista kielitiedettä ja sen alalla käytyä keskustelua empiirisen tutkimuksen luonteesta ja sen tarpeesta. He lähtevät liikkeelle suuntauksen lähtökohdista nostamalla esiin Lakoffin (1990) esittämät sitoumukset kognitiivisuudesta (cognitive commitment) ja yleistettävyydestä (generalization commitment). Kognitiivinen sitoumus tarkoittaa sitä, ettei kieltä katsota kognition erilliseksi alueeksi vaan sellaiseksi, joka toimii holistisesti muiden kognitiivisten alueiden (havaitsemisen huomion, tilan hahmottamisen tms.) kanssa. Yleistettävyys taas merkitsee sitä, että kielijärjestelmän eri komponentit (fonologia, morfologia, syntaksi, semantiikka ja pragmatiikka) toimivat kaikki yhdessä sulautuvasti eivätkä modulaarisesti. Toimittajat korostavat myös Langackerin $(1987,1999)$ näkemystä kieliopin ja merkityksen erottamattomuudesta ja kieliopista maailman käsitteistämisenä (conceptualization) tietynlaiseksi. Niinpä kognitiivinen kielitiede määritellään merkityskeskeiseksi ja käyttöpohjaiseksi eli kielenkäytöstä tehtyihin havaintoihin pohjautuvaksi suuntaukseksi (s. 1, 3; ks. myös Langacker 2008).

Toimittajat toteavat, että isojen aineistojen käsittelyn mahdollistavat nykyään kieliteknologiset ja laskennalliset työkalut, joiden kehityksen myötä korpusten käyttö on monipuolistunut. Tätä kehitystä on nimitetty empiiriseksi käänteeksi (s. 3-4). Käytännössä tämä tarkoittaa näkemystä, jonka mukaan merkityksen mahdollisimman tarkan kuvauksen saavuttamiseksi kannattaa hyödyntää todellisesta kielenkäytöstä peräisin olevia aineistoja monipuolisesti ja, aineiston 
salliessa, analysoida niitä myös määrällisesti. Juuri tähän teos pyrkii, kuten jo sen alaotsikosta voi havaita (Analyzing reallife data). Toimittajien mukaan tämä näkemys on käyttöpohjaisuuden luonnollinen laajentuma; varhaiset perusteokset (esim. Talmy 1986; Langacker 1987, 1988; Lakoff 1987) pohjautuivat etupäässä keksittyihin esimerkkeihin. Samalla he nostavat keskeiseksi keskustelunaiheeksi suhteet intuition, introspektion ja empiirisen aineiston välillä: Mitä kaikkea empiirinen aineisto voi olla? Miten intuitio eroaa introspektiosta, ja onko kummallakaan sijaa empiirisessä tutkimuksessa? Mitä ovat empiiristen aineistojen eri analyysimenetelmät? (Vrt. Itkonen \& Pajunen 2010.)

Analyysimenetelmien empiirisyys on oikeastaan asteittaista. Ääripäinä voidaan erottaa aineistoesimerkein tuettu (corpusillustrated) tutkimus, jossa aineistosta lähinnä poimitaan teoriaan sopivia esimerkkejä, ja aineistopohjainen (corpus-based) tutkimus, jossa teoreettista ymmärrystä rakennetaan tai koetellaan empiirisen aineiston laajamittaisen analyysin avulla (vrt. Jantunen 2009). Aineistopohjaisten lähestymistapojen tarkemmassa erottelussa on käytetty myös käsitteitä aineistokeskeinen (corpus-oriented) ja aineistovetoinen (corpus-driven), joista jälkimmäinen on vähiten introspektiivinen (s. 4-11).

\section{Korpuspohjaista tutkimusta}

Kokoelman ensimmäinen osio ("Corpusbased studies") koostuu viidestä artikkelista, jotka edustavat korpusaineistoon pohjautuvaa tutkimusta. Kolmessa ensimmäisessä artikkelissa yhdistetään laadullisia ja määrällisiä menetelmiä, kun taas kaksi viimeistä keskittyy perinteisempään laadulliseen analyysiin.

Osion aloittaa Tuomas Huumon, AkiJuhani Kyröläisen, Jenna Kanervan, M. Juhani Luotolahden, Tapio Salakosken, Filip Ginterin ja Veronika Laippalan artik- keli "Distributional semantic of the partitive A argument construction in Finnish". Artikkelissa tarkastellaan transitiivilauseen partitiivisubjektia (esim. useita autoja on reputtanut testin), joka muistuttaa muodoltaan objektia mutta merkitykseltään ja lauseasemaltaan rajaamatonta subjektia. Artikkelin fokus on erityisesti argumenttirakenteen ominaisuuksissa ja partitiivisubjektin distribuutiossa muun muassa predikaattiverbin semantiikan näkökulmasta. Aineistona on jatkuvasti kasvava Finnish Internet Parsebank -korpus, joka kerää automaattisesti aineistoa suomenkielisestä internetistä ja annotoi sitä morfosyntaktisesti. Tällainen laaja-alainen korpus soveltuu erinomaisesti partitiivisubjektin kaltaisten, kielenkäytössä melko harvinaisten ilmiöiden tutkimiseen. Analyysissa hyödynnetään semanttisia vektorimalleja, joiden avulla analysoidaan partitiivisubjektin kanssa esiintyvien verbien frekvenssejä ja semantiikkaa. Tutkimus vahvistaa yhtäältä aiempien tutkimusten tuloksia partitiivisubjektillisen lausekonstruktion matalasta transitiivisuudesta ja toisaalta osoittaa vahvan korrelaation konstruktiossa esiintyvien verbien frekvenssin ja semanttisten piirteiden välillä.

Jukka Mäkisalon ja Marjatta Lehtisen artikkelissa "Changes in figure-ground alignment in translation: Condensing information in subtitling" päästään käännöstieteen ääreen. Kaksikko tutkii informaation tiivistämistä ja poisjättämistä suomenkielisissä elokuvatekstityksissä. Tutkijat hakevat vahvistusta aiemmin esittämälleen kognitiivisen pysyvyyden hypoteesille (cognitive retention hypothesis), jonka mukaan kognitiivinen taso (eli merkitysrakenne) säilyisi käännöksessä paremmin kuin kielellinen taso, vaikka käännösvastaavuuksien tarkastelussa on perinteisesti keskitytty tarkastelemaan juuri jälkimmäistä (ks. Mäkisalo \& Lehtinen 2014). Kognitiivista tasoa tarkastellaan kuvio-tausta-käsiteparin avulla tut- 
kimalla englanninkielisen elokuvan repliikkejä ja niiden suomenkielisiä tekstityskäännöksiä. Tutkimus todentaa oletuksen siitä, että repliikkien kääntämisessä - eli puhutusta modaliteetista kirjoitettuun siirtymisessä - kognitiivinen rakenne säilyy paremmin kuin kielellinen rakenne. Lisäksi havaitaan, että ruututeksteissä on enemmän kognitiivisen tason muutoksia kuin tekijöiden aiemmin (ma.) tarkastelemissa asiaproosakäännöksissä.

Marja Nenosen, Juha Mullin, Alexandre Nikolaevin ja Esa Penttilän artikkelissa "How light can a light verb be? Predication patterns in $\mathrm{V}+\mathrm{NP}$ constructions in English, Finnish, German, and Russian" vertaillaan niin sanottujen funktioverbien (light verbs) käyttöä englannissa, saksassa, suomessa ja venäjässä. Kyse on verbeistä, joiden leksikaalinen merkitys on vähäinen (esim. antaa pusu - pussata). Tutkimus koostuu kahdesta osasta. Ensimmäisessä tarkastellaan verbien semantiikkaa sellaisissa idiomaattisissa VP-konstruktioissa, jotka sisältävät ruumiinjäsentä ilmaisevan substantiivin (esim. pitää päänsä). Analyysi osoittaa, että tavallisimmat verbit, jotka esiintyvät tällaisissa konstruktioissa, ovat eri kielissä hyvin samankaltaisia ja luokitettavissa nimenomaan funktioverbeiksi (suomessa esim. olla, saada, panna, mennä).

Tutkimuksen toinen osa on tapaustutkimus, jossa keskitytään tarkastelemaan määrällisin menetelmin 'ottaa'-merkityksisten verbien käyttötapoja tekstiaineistossa. Pyrkimyksenä on selvittää, milloin tällaisella verbillä on täysi leksikaalinen merkitys (esim. yhdistykseen otetaan lisää jäseniä), milloin merkitys on niin sanotusti kevyt (Schmitt otti kauden kahdeksannen voittonsa) ja milloin merkitys on sidoksissa koko konstruktioon, jossa verbiä käytetään, eikä seuraa yksin verbin merkityksestä (järjestelmä otettiin Suomessa käyttöön 1906). Analyysin tuloksena esitetään verbin merkityksen "keveyden" jatkumo, jolle verbit ovat ase- tettavissa kontekstin antamien tulkintavihjeiden perusteella.

Salla Nurminen puolestaan tarkastelee väitöskirjatutkimukseensa pohjautuvassa artikkelissaan "Expressing boundaries: A contextual approach to clausal aspect in Finnish" aspektin ilmaisemista suomen kielessä - etenkin geneeristen ja kieltomuotoisten lauseiden näkökulmasta. Nurminen toteaa, että siinä missä aspektia on aiemmin tutkittu lähinnä keksittyjen esimerkkien pohjalta, hän itse lähestyy ilmiötä empiirisesti, analysoimalla lehtiaineistosta systemaattisesti poimittuja esimerkkejä (n. 2 ooo lausetta). Hänen mukaansa kestoa ja toistuvuutta ilmaisevat adverbiaalit (esim. tunnin, joka viikko) eivät säätele lauseen aspektuaalista luentaa niin voimakkaasti kuin aiemmin on ajateltu. Sen sijaan tapahtumien ajankohtaa ilmaisevilla adverbiaaleilla (esim. tänään, viime vuonna) on aspektin tulkinnassa luultua isompi merkitys. Nurminen tarjoaa lisäksi uudenlaisen näkökulman lauseen aspektiin: siinä missä aspektia on aiemmin kuvattu lauseenjäsenten näkökulmasta, Nurminen laajentaa perspektiiviä ja ottaa näkökulmaksi koko lauseen. Hän katsoo, että aspektitulkintaan vaikuttaa eri rajattuuden ja rajaamattomuuden tasojen kerroksellisuus, jota voidaan tarkastella lauseenjäsenten kerrostumisen lisäksi myös lausekokonaisuuden eri tasojen kerrostumisena. Nurminen osoittaa samalla, että geneeriset, kielteiset sekä modaaliverbejä voida ja pitää sisältävät lauseet muistuttavat toisiaan aspektuaalisten tasojen osalta: Koska kaikki nämä kuvaavat tapahtumaa, joka ei sijoitu välittömään, tunnettuun todellisuuteen, niihin kohdistuu lauseen kuvaamia yksittäisiä tapahtumia koskevien tasojen lisäksi aina ylimääräinen rajaamattomuuden taso. Toisin sanoen ne on mahdollista tulkita rajaamatonta ja epäspesifistä, mahdollista tilannetta kuvaaviksi.

Ensimmäisen osion viimeisessä artikkelissa "The natural translation of 
idiomatic constructions" Esa Penttilä tarkastelee englanninkielisten idiomien spontaaneja suomenkielisiä käännöksiä (esim. kick the bucket - potkaista sankoa) piilevänä koodinvaihtona (concealed code switching). Tutkimuskohdetta on lähes mahdotonta tunnistaa koneellisesti, minkä vuoksi Penttilän lähestymistapana on aineistoesimerkein tuettu (corpusillustrated) laadullinen analyysi. Aineistona on internetistä poimittuja esiintymiä idiomien spontaaneista suomenkielisistä käännöksistä. Esiintymät hän on kerännyt hakemalla potentiaalisia käännöksiä yksitellen, esimerkkeinä rampa ankka (engl. lame duck) ja apina selässä (a monkey on one's back). Penttilän tarkoituksena on hahmotella ilmiön olemusta ja samalla pohtia sitä, miten ilmiötä voi ylipäänsä tutkia. Penttilä selittää, että kun tietyn idiomin spontaania käännöstä käytetään ensimmäistä kertaa keskustelussa, kaikkien osallistujien tulisi olla tietoisia sen olemassaolosta alkuperäisellä kielellä, jotta käännöslainan käyttö kyseisessä tilanteessa onnistuisi. Mitä enemmän käännöslaina konventionaalistuu kohdekielessä, sitä vähemmän taustatietoa alkuperäisestä idiomista tarvitaan. Penttilän mukaan käännöslainoja esiintyy monenlaisissa käyttökonteksteissa, niin verkkokeskustelussa kuin lehtiteksteissä. Metodologisesti hän ehdottaa, että ilmiön tutkimuksessa voitaisiin hyödyntää myös kokeellisia menetelmiä, esimerkiksi kyselytutkimusta taikka elisitaatioon tai reaktioajan mittaukseen pohjautuvia metodeja. Nämä voisivat tarjota tietoa siitä, kuinka iskostuneita tietyt käännöslainat ovat.

\section{Kyselyihin ja koejärjestelyihin perustuvaa tutkimusta}

Toinen osio ("Research based on information from language users") koostuu neljästä artikkelista, joissa analysoidaan kyselyin tai kokeellisesti kerättyä aineistoa. Lisäksi kaikissa paitsi yhdessä artik- kelissa hyödynnetään myös perinteistä korpusaineistoa, jolloin kyse on monimenetelmäisestä tutkimuksesta.

Milla Luodonpää-Manni tutkii artikkelissaan "The choice between generic scientific terms in linguistic research articles written in Finnish" 12 tieteellisen termin käyttöä ja vaihtelua suomenkielisissä kielitieteellisissä artikkeleissa. Tarkastelussa ovat muun muassa termit teoria, hypoteesi, malli, metodi ja menetelmä. Tutkimuksen ensimmäisessä vaiheessa lingvisteiltä kerättiin tietoa termien käytöstä kyselytutkimuksen avulla (ks. Luodonpää-Manni 2013). Käsillä olevassa artikkelissa kyselyn tuloksia verrataan autenttiseen kielenkäyttöön; aineistona on 60 suomenkielisen tutkimusartikkelin korpus. Tutkimustulokset viittaavat siihen, että kyseisten tieteellisten termien käyttöön ja vaihteluun vaikuttavat monet käsitteelliset, epistemologiset ja tyylilliset tekijät: termin valintaa voi ohjata esimerkiksi tiedon varmuus (esim. teoria vs. hypoteesi) tai toisaalta toiston välttäminen tekstissä. Tutkimus tarjoaa metalingvistisen näkökulman kielitieteellisen diskurssin tutkimukseen.

Osion toisessa artikkelissa "Topicmarking prepositions in Spanish: Contrasting corpus and questionnaire data in the analysis of prepositional synonymy" Anton Granvik selvittää puheenaihetta ilmaisevien (topic-marking) prepositioiden välisiä käyttöeroja espanjassa. Tutkittavana ovat lähisynonyymeiksi katsotut prepositiot de, sobre, acerca de ja en torno a; kaikkien käännösvastine on puheenaihetta ilmaiseva elatiivi (esim. mitä ajattelet tästä?). Menetelminä yhdistetään kyselytutkimusta ja multinomiaalista logistista regressioanalyysia (multinomial logistic regression analysis). Jälkimmäisen avulla voidaan tutkia tekijöitä, jotka vaikuttavat useamman vaihtoehdon väliltä valitsemiseen. Regressioanalyysin aineistona on sata Corpus del español -aineistosta satunnaisotannalla poimittua esiintymää 
kustakin prepositiosta. Analyysi näyttää, että siinä missä prepositiot de ja en torno $a$ ovat käytöltään melko spesifejä, sobre ja acerca de ovat hyvin joustavia ja monikäyttöisiä. Analyysin perusteella Granvik esittää, että kyseiset prepositiot ovat saman puheenaihetta ilmaisevan konstruktion alakonstruktioita. Prepositioilla on Granvikin mukaan enemmän yhdistäviä kuin erottavia piirteitä, minkä vuoksi hän pitää niitä toistensa lähes täydellisinä synonyymeina. Jatkotutkimuksessa voisi kenties tarkastella, onko rekisterillä ja tyylillä vaikutusta preposition valintaan.

Aki Kyröläisen, Vincent Porrettan ja Juhani Järvikiven artikkeli "The role of morphological verb constructions in processing Russian reflexive verbs" esittelee kokeellisen tutkimuksen venäjän kielen refleksiiviverbien prosessoinnista. 160 refleksiiviverbiin pohjautuvan tutkimuksen ytimessä on leksikaalisen päätöksenteon tehtävä (lexical decision task), jossa koehenkilöille esitettiin sekä oikeita sanoja (verbejä) että epäsanoja; tehtävänä oli arvioida mahdollisimman nopeasti, onko verbi olemassa venäjän kielessä vai ei. Tämän jälkeen selvitettiin arviointitehtävän avulla informanttien näkemykset refleksiivijohdoksen ja sen kantaverbin samankaltaisuudesta. Tietoa verbien yksittäisten morfeemien frekvensseistä haettiin Venäjän kansalliskorpuksesta (Russian National Corpus) soveltamalla pääkomponenttianalyysia (principal component analysis). Analyysin perusteella refleksiiviverbien prosessointiin vaikuttaa refleksiivijohdoksen suhde kantaverbiin ja toisaalta kokonaisuuden morfologinen rakenne.

Lopuksi Maija Surakka tarkastelee artikkelissaan "Development of early directives in Finnish: A usage-based approach" suomenkielisen leikki-ikäisen (kaksikolmivuotiaan) pojan tuottamien direktiivien eli tahdon ilmausten kehittymistä. Aineisto koostuu äänitallenteista ja päiväkirjametodilla kerätyistä ilmauksista. Surakan pyrkimyksenä on analysoida lap- sen tuottamia lausumia suhteessa niiden skemaattisiin merkitysrakenteisiin eli käsitteistyksiin. Analyysi on multimodaalista: Surakka huomioi sen, kuinka lapsen ja vanhemman vuorovaikutus tukeutuu myös ei-kielellisiin keinoihin, kuten eleisiin ja ilmeisiin. Merkityksiä välittävien multimodaalisten rakenteiden identifioiminen on keino seurata lapsen kehitystä sekä kieliopillisella että käsitteellisellä tasolla. Tutkimus osoittaa, että varhaisvaiheessa lapsi tuotti tahdon ilmauksia epäsuorasti, kommentoimalla omaa toimintaansa (esim. lapsi nimeltä X sanoo "X istuu" ilmaistakseen halunsa istua). Myöhemmässä vaiheessa lapsi ilmaisi tahtoaan kommentoimalla myös muiden toimintaa (esim. "Ei isi vie vaatteet"). Lisäksi sitä mukaa, kun lapsi pääsi havainnoimaan muiden osallistujien toimintaa ja olemaan vuorovaikutuksessa heidän kanssaan, hänen tuottamistaan rakenteista tuli kompleksisempia ja imperatiivin käytöstä sujuvampaa. Surakan aineisto perustuu ainoastaan yhden lapsen kielenomaksumisen tarkasteluun, joten tuloksista ei voi vetää kovin yleispäteviä johtopäätöksiä. Artikkelin ansio on monipuolinen ja multimodaalinen lähestymistapa kielioppiin, kielenomaksumiseen ja intersubjektiivisuuteen.

\section{Lopuksi}

Luodonpää-Mannin ja kumppanien toimittama teos tarjoaa hyvän katsauksen käyttöpohjaisten menetelmien moninaisuuteen kognitiivisessa kielentutkimuksessa. Teoksen artikkeleissa esitellyissä tutkimuksissa noudatetaan monimenetelmäistä lähestymistapaa. Taustaajatuksena on se, että koska kieli on hyvin monitahoinen ilmiö, sen tutkimuksessa on tarpeen hyödyntää monipuolisesti laadullisia ja määrällisiä menetelmiä. Käyttöpohjaisten lähestymistapojen kirjon esittely lieneekin teoksen parasta antia: lukija pääsee monipuolisten aihepii- 
rien ja käyttöpohjaisuuteen perustuvien tutkimusmenetelmien ääreen. Hieman harmittamaan jää toisaalta se, että kognitiivisen otteen lisäksi juuri muuta yhteistä tematiikkaa teoksen artikkeleiden välillä ei tunnu olevan.

Teos ei ole kannesta kanteen luettava oppikirja vaan kokoelma, jossa lukija voi tutustua haluamiinsa empiirisiin metodeihin erilaisten esimerkkitutkimusten kautta. Kognitiivisen kielentutkimuksen suuntaukset eivät muodosta yhtenäistä koulukuntaa vaan ovat hyvin eklektisiä, mitä teos heijastaa hyvin. Teoksen jako kahteen osioon ja osioiden sisäinen eteneminen menetelmällisen samankaltaisuuden pohjalta on lukijan kannalta toimiva ratkaisu. Toisaalta teos vaatii lukijalta varsin paljon, sillä artikkelit on kirjoitettu eri näkökulmista ja ne edellyttävät erilaisia taustatietoja. Niinpä suosittelenkin sitä ennen muuta akateemiselle lukijakunnalle, yliopisto-opiskelijoille ja tutkijoille, joita kiinnostaa aineistojen ja menetelmien moninaisuus, erityisesti määrälliset, kokeelliset tai monimenetelmäiset lähestymistavat yhdistettyinä kognitiiviselle kielentutkimukselle ominaisiin kysymyksenasetteluihin.

$$
\begin{array}{r}
\text { GAÏDIG DuBOıs } \\
\text { gaidig.sukunimi@helsinki.fi } \\
\text { Kirjoittaja on suomen kielen väitöskirja- } \\
\text { tutkija Helsingin yliopistossa. }
\end{array}
$$

\section{Lähteet}

Huumo, Tuomas 1997: Lokativit lauseen semanttisessa tulkinnassa. Ajan, omistajan, paikan ja tilan adverbiaalien keskinäiset suhteet suomen kielessä. Turun yliopiston suomalaisen ja yleisen kielitieteen laitoksen julkaisuja 55. Turku: Turun yliopiston suomalaisen ja yleisen kielitieteen laitos.

Itkonen, Esa - Pajunen, Anneli 2010:
Empiirisen kielitieteen metodologia. Helsinki: Suomalaisen Kirjallisuuden Seura.

JANTUNEN, JARMO 2009: Ei pelkästään mielikuvituksen puutteen vuoksi - kieliaineistojen systemaattinen käyttö kielentutkimuksessa. - Virittäjä 113 s. 101-113.

LAkoff, George 1987: Women, fire, and dangerous things. What categories reveal about the mind. Chicago: University of Chicago Press.

- 1990: The invariance hypothesis. Is abstract reason based on image-schemas? - Cognitive Linguistics 1 s. 39-74.

LANGACKer, RonAld W. 1987: Foundations of cognitive grammar. Volume I. Theoretical prerequisites. Stanford: Stanford University Press.

_ 1988: A usage-based model. - Brygida Rudzka-Ostyn (toim.), Topics in cognitive linguistics s. 127-161. Amsterdam: John Benjamins. https://doi.org/10.1075/ cilt.50.o6lan.

1999: Grammar and conceptualization. Berlin: Mouton de Gruyter.

- 2008: Cognitive grammar. A basic introduction. Oxford: Oxford University Press.

Leino, Pentti 1988: Kieli tilakieliopin kehyksessä nähtynä. - Jan-Ola Östman, Urpo Nikanne, Kristiina Jokinen \& Kalevi Wiik (toim.), Suomen kielitieteellisen yhdistyksen vuosikirja s. 123-142. Helsinki: Suomen kielitieteellinen yhdistys.

1989: Paikallissijat ja suhdesääntö. Kognitiivisen kieliopin näkökulma.

- Virittäjä 93 s. 161-219.

_ 1993: Suomen kielen kognitivista kielioppia 1. Polysemia - kielen moniselitteisyys. Kieli 7. Helsinki: Helsingin yliopiston suomen kielen laitos.

Luodonpä̈̈-Manni, Milla 2013: Kyselytutkimus kielentutkijoiden yleistieteellisille termeille antamista merkityksistä. - Virittäjä 117 s. 242-264.

Mäkisalo, Jukka - Lehtinen, MarJATTA 2014: Dissociation of linguistic and cognitive description in translation. 
The cognitive Figure-Ground alignment. - Heli Paulasto, Lea Meriläinen, Helka Riionheimo \& Maria Kok (toim.), Language contacts at the crossroads of disciplines s. 191-211. Newcastle upon Tyne: Cambridge Scholars Publishing. Möttönen, TAPAni 2016: Construal in expression. An intersubjective approach to cognitive grammar. Helsinki: Helsingin yliopisto.

Nurminen, SAlla 2015: Lauseen aspektin ilmaiseminen suomen kielessä. Tutkimus olla-, tehdä- ja tulla-verbillisistä tekstilauseista käyttökonteksteissaan. Annales Universitatis Turkuensis C 410. Turku: Turun yliopisto.

Onikki-RantajÄÄskö, TIIna 2001: Sarjoja. Nykysuomen paikallissijaiset olotilanilmaukset kielen analogisuuden ilmentäjinä. Suomalaisen Kirjallisuuden Seuran Toimituksia 817. Helsinki: Suomalaisen Kirjallisuuden Seura.

TALMY, LEONARD 1986: The relation of grammar to cognition. Essen: Linguistic Agency University of Duisburg-Essen LAUD.

\section{Monipuolisesti rakenteiden ja toimintojen yhdistämisestä vuorovaikutuksessa}

\author{
Ritva Laury, Marja Etelämäki \& Elizabeth \\ Couper-Kuhlen (toim.): Linking clauses \\ and actions in social interaction. Helsinki: \\ Suomalaisen Kirjallisuuden Seura 2017. \\ 243 s. ISBN 978-952-222-858-1.
}

Linking clauses and actions in social interaction on Ritva Lauryn, Marja Etelämäen ja Elizabeth Couper-Kuhlenin toimittama, kahdeksasta itsenäisestä tutkimusartikkelista muodostuva kokoomateos. Nimensä mukaisesti siinä syvennytään tarkastelemaan rajattua vuorovaikutuksellista ilmiötä, kieliopillisten rakenteiden ja sosiaalisten toimintojen yhdistämistä (linking). Toimittajat kertovat teoksen pohjautuvan Suomen Akatemian vuosina 2009-2013 rahoittamaan tutkimushankkeeseen, jossa tarkasteltiin yhdistämisilmiöitä puheessa ja kirjoituksessa; kokoelmassa pääpaino on kuitenkin vahvasti puhutun vuorovaikutuksen tutkimuksessa.
Teoreettisena viitekehyksenä on pääosin joko keskustelunanalyysi tai sen pohjalta kehitetty vuorovaikutuslingvistiikka (ks. Couper-Kuhlen \& Selting 2001).

Yhdistämistä lähestytään teoksessa moniulotteisena ilmiönä, ja se määritellään väljästi: yhdistäminen merkitsee toimintojen, vuorojen tai rakenteiden asettamista keskinäiseen suhteeseen (s. 13). Kokoelman artikkeleissa selvitetään muun muassa, millaisia resursseja yhdistämiseen käytetään, millaisia elementtejä voidaan yhdistää toisiinsa ja miten etäisiä yhdistettävät elementit voivat olla ajallisesti. Artikkelien empiiriset aineistot ovat niin ikään monipuolisia: elementtien yhdistämistä tarkastellaan arkikeskustelujen ohella luokkahuonevuorovaikutuksessa, tanssiopetuksessa sekä mediakonteksteissa. Teos vakuuttaa lukijansa siitä, että toimintojen ja rakenteiden yhdistäminen on kaikenlaisia vuorovaikutustilanteita läpäisevä ilmiö. 